\title{
Grain size and leaching test analysis of fly ash from sludge incinerator
}

\author{
Róbert Polc ${ }^{1}$ L Lubomír Jurkovič² \\ ${ }^{1}$ SLOVNAFT, a.s., SD \& HSE, Department of Environmental Protection; Vlčie hrdlo 1, 824 12, Bratislava, Slovakia; \\ e-mail: robert.polc@slovnaft.sk \\ ${ }^{2}$ Comenius University in Bratislava, Faculty of Natural Sciences, Department of Geochemistry; \\ Mlynská dolina, 84215 Bratislava, Slovakia; e-mail: jurkovic@fns.uniba.sk
}

(C) 2015 Authors. This is an open access publication, which can be used, distributed and reproduced in any medium according to the Creative Commons CC-BY 4.0 License requiring that the original work has been properly cited.

The contribution deals with grain size analysis and leaching test of fly ash as a solid waste from gas treatment technology at sludge incinerator. Grain size analysis and leaching test was carried out to determine hazardous substances which have adverse effect on environment. Sludge incinerator is a part of petrochemical complex and it's used for ecological disposal of mechanical and biological sludge from the wastewater treatment plant (Géci 2013). Incineration technology of thermal oxidation is divided in two steps. In first step mixed sludge is warmed, dried and organic matter is burned off. In second step flue gas emissions are cleaned in four-step cleaning technology to keep up air emission quality. Product of the treated gas, during combustion process, is fly ash where annually production is approximately $600 \mathrm{t}$ per year (Polc et al. 2013) and depends on chemical composition of burned sludge, working time per year and air emission quality.

Fly ash is a mixture of inorganic compounds, salts of acidic flue gas components dissolved in water (fluorides, sulphates) and insoluble components (zeolite and activated carbon). It is a fine powder of light brown to light grey color. It contains unreacted $\mathrm{NaHCO}_{3}, \mathrm{Na}_{2} \mathrm{SO}_{3}, \mathrm{Na} 2 \mathrm{SO} 4, \mathrm{NaCl}, \mathrm{NaF}$ (Špak et al 2012, Polc et al. 2013), further small content of silicon, calcium, magnesium, iron, sodium and potassium oxides and traces of heavy metals adsorbed on the zeolite and activated carbon. The samples used for mineralogical composition were then studied at diffractometer Philips PW 1710. $\mathrm{X}$-ray diffraction sample record has a relatively high background, indicating the presence of amorphous phase (23.1 wt. \%), which seems to be the amorphous glass or unburnt organic material. Mineral phase gehlenite (46.9 wt. \%) has the highest proportion in the sample, followed by maghemite (12.7 wt. \%), hematite (6 wt. \%) and thenardite (6 wt. \%). In granulometry analysis has been shown that fly ash is very fine material, were $97 \%$ mass fraction is under $0.09 \mathrm{~mm}$ grain size. Overall results are that $2 \%$ of mass fraction is under $0.04 \mathrm{~mm}$ gran size, $79 \mathrm{wt}$. \% under $0.063 \mathrm{~mm}, 97.0 \mathrm{wt}$. \% under $0.09 \mathrm{~mm}$, 99 wt. $\%$ under $0.125 \mathrm{~mm}$ and 100 wt. \% under $0.25 \mathrm{~mm}$ grain size.

In leaching test, there was in execution potential of hazardous compounds discharge to environment. Leaching test was executed in water solution according Annex 22 and 23 of the Decree No. 310/2013, which implements certain provisions of the Waste Act and this method is suitable mainly for inorganic parts of waste. Leaching of trace elements from ash is affected by the chemical composition of the solution during weathering distribution of these elements in the solid matrices and secondary phases. Secondary phases produced during weathering, have a significant control to their mobility in ash (Eary et al. 1990). 
Given that the flue gas cleaning technology aims to reduce emissions of acidic compounds into the atmosphere. Therefore there is the "enrichment" of these components in the waste, which leads to concentration of fluorides, sulphates, and other components in leachate. Potentially toxic elements shows decreasing leaching tendency from $\mathrm{Al}>\mathrm{V}>$ $\mathrm{Pb}>\mathrm{Mo}>\mathrm{As}>\mathrm{Sn}>\mathrm{Zn}$.

According to high proportion of acidic components and fine fraction, leaching is also an important parameter in terms of determine the way of next handling (landfilling) of fly ash. The stabilization of waste is particularly important because of the potential leaching of acidifying components - fluoride, sulfate and total dissolved solids into environment.

\section{REFERENCES}

Annex 22 and 23 of the Decree No. 310/2013, which implements certain provisions of the Waste Act.

Eary L.E., Rai D., Mattigod S.V. \& Ainsworth C.C., 1990. Geochemical factors controlling the mobilization of inorganic constituents from fossil fuel combustion residues: II. Review of the minor elements. Journal Environmental Quality, 19, 202-214.

Géci M., 2013. Prevádzkový poriadok zariadenia Spalovňa kalov MCHB ČOV z 30.7.2013. P-7 Vodné hospodárstvo, SLOVNAFT, Vlčie hrdlo, Bratislava.

Polc R., Jurkovič L., Milička J. \& Pörsök M., 2013. Základné parametre produktov čistenia spalín vznikajúcich zneškodňovaním tuhých odpadov spalovaním. [in:] Jurkovič L., Slaninka I. \& Durža O. (eds), GEOCHÉMIA 2013, Zborník vedeckých príspevkov ŠGÚDŠ, Bratislava, 143-145.

Špak M., Halaša I., Šuster M. \& Vojtechovský O., 2012. Informácie o používaní popolčeka do betónu. BetónRacio, Trnava. 